\title{
UJI EFEK ANTIDIABETES KOMBINASI EKSTRAK HERBA SAMBILOTO (Andrographis paniculata (Burm. F.) Nees.) DAN DAUN SIRSAK (Annona muricata L.) PADA TIKUS JANTAN YANG DIINDUKSI ALOKSAN
}

\author{
Maya Dwi Anggraini ${ }^{1}$, Eka Wisnu Kusuma ${ }^{2}$ \\ ${ }^{1}$ Program Studi D3 Farmasi, Sekolah Tinggi Ilmu Kesehatan (STIKES) Nasional Surakarta \\ ${ }^{2}$ Program Studi S1 Farmasi, Sekolah Tinggi IImu Kesehatan (STIKES) Nasional Surakarta \\ Email: kusuma.3ka@gmail.com; mayadwianggraini98@gmail.com
}

\begin{abstract}
Diabetes mellitus(DM) is a disease characterized by an increase in blood sugar levels above normal. A lot of research about the medicine focusing on the use of plants that can be used in traditional medicines. This report is to know the combination of extract ethanol sambiloto herb and leaves the soursop to lower blood glucose levels on male rats wistar are induced alloxan. The research is an experimental research to pre and post test randomized controlled group. Treatment test consists of 8 groups: normal control, negative (alloxan), positive (glibenclamide 1,26 mg/kgBB), dose I SA 100 (sambiloto herb 20,5 mg/kgBB), dose II SR 100(leaves the soursop100 mg/kgBB), dose III SA:SR 25:75, dose IV SA:SR 50:50, dose V SA:SR 75:25. All groups (except normal) induced by alloxan $160 \mathrm{mg} / \mathrm{KgBB}$. Then proceed with treatment test each drug group from day 0 to 14 in oral. Intake of blood glucose levels is done on days 0,7 and 14. The results of the measurement of blood glucose levels followed by ANOVA. Combination sambiloto herb and leaves the soursop more effective to reduce blood glucose levels than single. Doses combination SA:SR 50:50 give the efffect of $28,38073 \%$.
\end{abstract}

Key Words: Alloxan, diabetes mellitus, sambiloto herbs, soursop leaves.

\section{PENDAHULUAN}

Diabetes melitus (DM) merupakan penyakit metabolik yang disebabkan karena kelainan sekresi insulin ditandai dengan meningkatnya kadar glukosa darah. ${ }^{1}$ Hasil survei WHO tahun 2005 Indonesia menempati peringkat ke-4, dimana terjadi peningkatan dari tahun ke tahun sehingga penyakit DM perlu mendapat perhatian dalam pengobatan. ${ }^{1}$ Glibenklamid adalah salah satu obat hipoglikemi oral yang diindikasikan untuk penderita DM tipe 2 dengan mekanisme kerja meningkatkan sekresi insulin. ${ }^{3}$

Daun sirsak mengandung senyawa flavonoid, tannin, fitosterol, kalsium oksalat, dan alkaloid. ${ }^{4}$ Senyawa flavonoid (quersetin) pada daun sirsak memiliki potensi hipoglikemik dengan menstimulasi sekresi insulin, memperbaiki kerusakan sel $\beta$ pankreas, inhibitor enzim $\alpha$-glukosidase ${ }^{5}$ dan Ekstrak daun sirsak memiliki aktivitas dalam proses penyembuhan luka scabies pada kambing kacang. ${ }^{6}$ Dosis optimal ekstrak etanol $100 \mathrm{mg} / \mathrm{kgBB}$ dapat berfungsi sebagai hipoglikemi pada tikus. ${ }^{7}$

Daun sambiloto memiliki kandungan kimia diantaranya deoksiandrografolid, andrografolid, noeandrografolid, 12didehidroandrografolid, dan homoandrografolid. ${ }^{8}$ Ekstrak herba sambiloto mengandung senyawa andrografolid dimana dalam jaringan (GLUT 4) terjadi penurunan kadar glukosa darah dan melalui penghambatan $\alpha$-glukosidase dalam saluran pencernaan. ${ }^{9}$ Ekstrak etanol daun sambiloto efektif menurunkan kadar gula darah pada mencit dengan dosis $29,25 \mathrm{mg} / \mathrm{kgBB} .{ }^{10}$ 
Uji efek antidiabetes kombinasi ekstrak herba sambiloto (Andrographis paniculata (Burm. F.) Nees.) dan daun sirsak (Annona muricata L.) pada tikus jantan yang diinduksi aloksan

\section{METODE PENELITIAN}

\section{Alat dan Bahan}

Daun sirsak (Annona muricata L.), herba sambiloto (Andrographis paniculata (Burm. F.) Nees.), tikus jantan berat 100-300 gram galur wistar, alloxan monohydrate (Aldrich), glibenklamid (Generik), CMC-Na, etanol $70 \%$, aquadest, reagen GOD-PAP (Dyasis), pakan hewan uji. Timbangan, mortir dan stamfer, ayakan, beaker glass, batang pengaduk, rotary evaporator, waterbath, cawan porselin, gelas ukur, pipa kapiler, tabung reaksi, eppendrop, hand gloves, spuit oral, mikrometer pipet, pipet tetes, yellow tip, alumunium foil, spektrofotometer, kapas, sarung tangan, masker, kandang hewan uji, nampan, kompor, dan sentrifugator.

\section{Prosedur penelitian}

\section{Determinasi Tanaman}

Determinasi tanaman berfungsi untuk proses dalam menentukan nama/jenis tumbuhan secara spesifik sehingga tidak terjadi kebingungan.

\section{Pembuatan Ekstrak Herba Sambiloto dan} Daun Sirsak

Sampel daun sirsak dan herba sambiloto disortasi basah dan dicuci dengan air mengalir, kemudian dikeringkan dengan cara diangin-anginkan. Setelah itu dilakukan sortasi kering dan penyerbukan. Serbuk herba sambiloto dan daun sirsak masing-masing ditimbang $300 \mathrm{~g}$ lalu diekstraksi dengan metode maserasi menggunakan cairan penyari etanol $70 \%(1: 7,5)$ selama 5 hari dan dilakukan pengadukan setiap harinya. Maserat disaring dengan kain flannel dan kertas saring. Filtrat yang didapat dikentalkan dengan rotary evaporator pada suhu $50^{\circ} \mathrm{C}$ dengan kecepatan 200 rpm kemudian diuapkan dengan waterbath listrik suhu $40^{\circ} \mathrm{C}$ sampai diperoleh ekstrak kental.

\section{Uji Kadar Gula Darah}

Hewan uji diadaptasikan selama 8-20 jam. Sebelum perlakuan semua hewan uji dipuasakan selama 12-18 jam. Hari ke-0 semua hewan uji diinduksi aloksan 160 $\mathrm{mg} / \mathrm{kgBB}$ (i.p) kecuali kontrol normal. Hari ke-1 sampai hari ke-14 masing-masing hewan uji diberi perlakuan secara P.O sesuai kelompok sebagai berikut:

a. Kelompok 1 (Normal) : Aquadest

b. Kelompok 2 (Negatif) : CMC-Na 0,5\%

c. Kelompok 3 (Positif) : Glibenklamid 1,26 $\mathrm{mg} / \mathrm{kgBB}$ )

d. Kelompok 4 (SA 100) : Ekstrak etanol herba sambiloto $(20,5 \mathrm{mg} / \mathrm{kgBB})$

e. Kelompok 5 (SR 100) : Ekstrak etanol daun sirsak (100 mg/kgBB)

f. Kelompok 6 (SASR 25:75) : Kombinasi ekstrak etanol herba sambiloto $25 \%$ : daun sirsak $75 \%$

g. Kelompok 7 (SASR 50:50) : Kombinasi ekstrak etanol herba sambiloto $50 \%$ : daun sirsak $50 \%$

h. Kelompok 8 (SASR 75:25) : Kombinasi ekstrak etanol herba sambiloto $75 \%$ : daun sirsak $25 \%$

Pemeriksaan kadar gula darah dilakukan pada hari ke-0 (sebelum diinduksi aloksan), ke-7, dan ke-14 dengan mengambil darah sebanyak $\pm 1 \mathrm{ml}$ melalui vena mata kemudian disentrifugasi selama 10 menit (3000 rpm). Serum darah dipipet sebanyak 10 $\mu \mathrm{l}$, kemudian ditambahkan GOD-PAP $1000 \mu \mathrm{l}$ dan dilakukan inkubasi selama 20 menit pada suhu $20-25^{\circ} \mathrm{C}$. Kemudian dibaca serapannya menggunakan alat spektrofotometer $\lambda 546 \mathrm{~nm}$. 
Uji efek antidiabetes kombinasi ekstrak herba sambiloto (Andrographis paniculata (Burm. F.) Nees.) dan daun sirsak (Annona muricata L.) pada tikus jantan yang diinduksi aloksan

Analisis Data

Data pengukuran kadar gula darah hari ke-0, ke-7, dan ke-14 dilakukan uji statistik SPSS ANOVA dengan taraf kepercayaan $5 \%$.

\section{HASIL DAN PEMBAHASAN}

Herba sambiloto didapat dari Desa

Maron RT 14/01 Kecamatan Karang Rejo

Kabupaten Magetan dan daun sirsak didapat dari Desa Jendi RT 02/05 Kelurahan Gambiranom Kecamatan Baturetno Kabupaten Wonogiri. Kedua tanaman dideterminasi di Laboratorium Biologi Universitas Muhammadiyah Surakarta untuk memastikan jenis tumbuhan sehingga tidak terjadi kesalahan. Tanaman dilakukan sortasi basah dengan air mengalir dan dikeringkan dengan cara diangin-anginkan dengan tujuan mencegah kerusakan kandungan metabolit terutama andrografolida dan flavonoid (quersetin) dalam sampel, selanjutnya dilakukan proses sortasi kering. Herba sambiloto dan daun sirsak yang telah melalui proses sortasi kering, kemudian dilakukan proses pengecilan ukuran (penyerbukan). Setelah dilakukan proses pengecilan ukuran selanjutnya masing-masing serbuk herba sambiloto dan serbuk daun sirsak ditimbang sebanyak $300 \mathrm{~g}$ untuk kemudian dilakukan proses ekstraksi dengan metode maserasi.

Maserasi dilakukan dengan menggunakan pelarut etanol $70 \%$ sebanyak 7,5 kali dari bobot sampel selama 5 hari dan dilakukan pengadukan setiap hari untuk menjaga agar pelarut yang digunakan tidak mengalami kejenuhan. Maserat yang diperoleh pada hari ke-5 dengan cara menyaring maserat menggunakan kain flannel kemudian maserat disaring kembali menggunakan kertas saring dengan tujuan untuk memastikan tidak ada serbuk simplisia yang ikut tersaring. Maserat yang telah disaring kemudian dikentalkan menggunakan rotary evaporator pada suhu $50^{\circ} \mathrm{C}$ dengan kecepatan $200 \mathrm{rpm}$, kemudian maserat dikentalkan kembali menggunakan waterbath listrik pada suhu $40^{\circ} \mathrm{C}$ hingga diperoleh ekstrak etanol daun sirsak dan ekstrak etanol herba sambiloto yang kental. Hasil rendemen yang diperoleh dari ekstrak etanol daun sirsak sebesar14,36\% dan ekstrak etanol herba sambiloto sebesar $13,97 \%$.

Pengujian penurunan kadar gula darah kombinasi ekstrak herba sambiloto dan daun sirsak menggunakan metode GOD-PAP. Hewan uji yang telah diadaptasikan selama 820 jam, kemudian dibagi ke dalam 8 kelompok yang masing-masing kelompok berjumlah 4 ekor. Pada hari ke-0 semua hewan uji diinduksi aloksan 160 mg/kgBB (i.p) kecuali kontrol normal. Hari ke-1 sampai hari ke-14 masing-masing hewan uji diberikan kelompok 1 (kontrol normal) hanya diberikan aquadest, kelompok 2 (kontrol negatif) diberikan CMC$\mathrm{Na}$ 0,5\%, kelompok 3 (kontrol positif) diberikan glibenklamid dengan dosis $1,26 \mathrm{mg} / \mathrm{kgBB}$, kelompok 4 diberikan SA 100, kelompok 5 diberikan SR 100, kelompok 6 diberikan kombinasi SASR 25:75, kelompok 7 diberikan kombinasi SASR 50:50, kelompok 8 diberikan kombinasi SASR 75:25.Pemberian perlakuan diberikan secara oral dan berdasarkan bobot masing-masing hewan uji.

Glibenklamid bekerja menurunkan kadar gula darah dengan cara meningkatkan pelepasan insulin dari pankreas. Mekanisme ini bergantung pada sel beta pankreas. Sulfonilurea menempel pada reseptor yang spesifik di sel beta pankreas dan menyekat pemasukan kalium melalui kanal ATP- 
Uji efek antidiabetes kombinasi ekstrak herba sambiloto (Andrographis paniculata (Burm. F.) Nees.) dan daun sirsak (Annona muricata L.) pada tikus jantan yang diinduksi aloksan

dependent. $^{11}$ Glibenklamid dipilih sebagai kontrol positif karena mekanisme kerja glibenklamid sesuai dengan model diabetes melitus yang dibuat pada hewan uji yaitu dengan diinduksi aloksan, sehingga terjadi penurunan sekresi insulin akibat rusaknya sel $\beta$ pankreas. Grafik kadar glukosa darah hewan uji masing-masing kelompok perlakuan dapat dilihat pada gambar 1 dan histogram rata-rata penurunan kadar gula darah masing-masing kelompok perlakuan dapat dilihat pada gambar 2.

Berdasarkan gambar 1 semua kelompok mempunyai kadar gula darah normal pada hari ke-0 sebelum diinduksi aloksan, kecuali kontrol normal. kelompok normal yang hanya diberikan aquadest tidak terdapat perbedaan bermakna glukosa darah mulai hari ke-0 sampai hari ke-14. ${ }^{12}$ Pada penelitian ini, kontrol normal yang hanya diberikan aquadest memiliki kadar gula darah diatas normal pada hari ke-0. Hal ini dapat disebabkan karena adanya faktor stress pada hewan uji dan pemberian pakan hewan uji.
Semua kelompok perlakuan mengalami kenaikan kadar gula darah pada hari ke-7 terutama kelompok negatif karena kelompok ini hanya diberikan aloksan dan CMC-Na yang tidak memiliki efek pengobatan. Kelompok positif mengalami kenaikan kadar glukosa darah hari ke-7 dan terjadi penurunan pada hari ke-14, hal ini disebabkan karena pemberian glibenklamid dengan dosis 1,26 $\mathrm{mg} / \mathrm{KgBB}$. Kelompok SA 100, SR 100, SASR 25:75, SASR 50:50 dan SASR 75:25 mengalami penurunan kadar gula darah pada hari ke-7 hingga hari ke-14. Hal ini menunjukkan kemungkinan adanya efek hipoglikemi pada dosis SA 100, dosis SR 100, serta kombinasi SASR $25 \%: 75 \%$, SASR 50\%:50\% dan SASR 75\%:25\%. Data rata-rata kadar gula darah yang diperoleh, kemudian diuji secara statistik menggunakan One Way Annova. Berdasarkan hasil analisis dari masing-masing kelompok perlakuan terdapat perbedaan signifikan atau mempunyai varian yang berbeda (sig. $<0,05$ ).

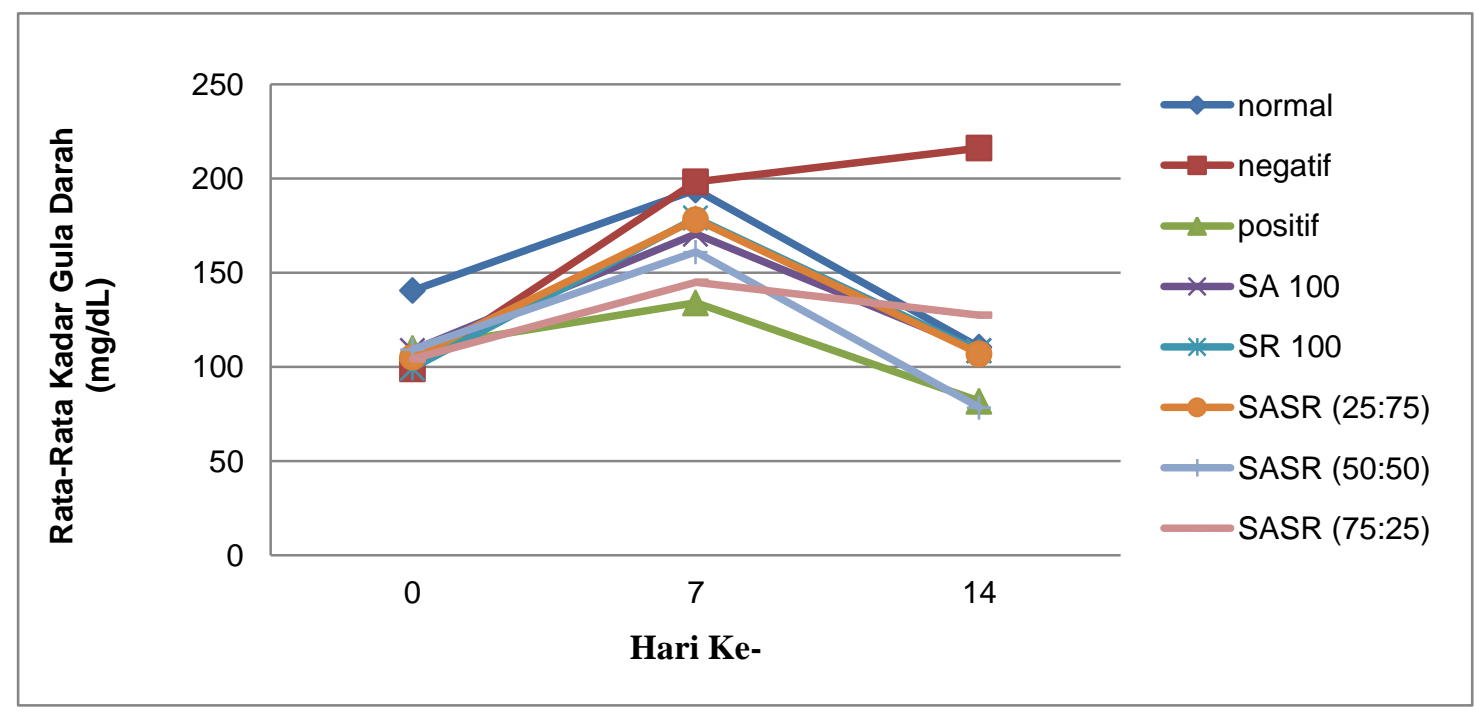

Gambar 1. Grafik kadar glukosa darah (mg/dl) hewan uji masing masing kelompok perlakuan 
Uji efek antidiabetes kombinasi ekstrak herba sambiloto (Andrographis paniculata (Burm. F.) Nees.) dan daun sirsak (Annona muricata L.) pada tikus jantan yang diinduksi aloksan

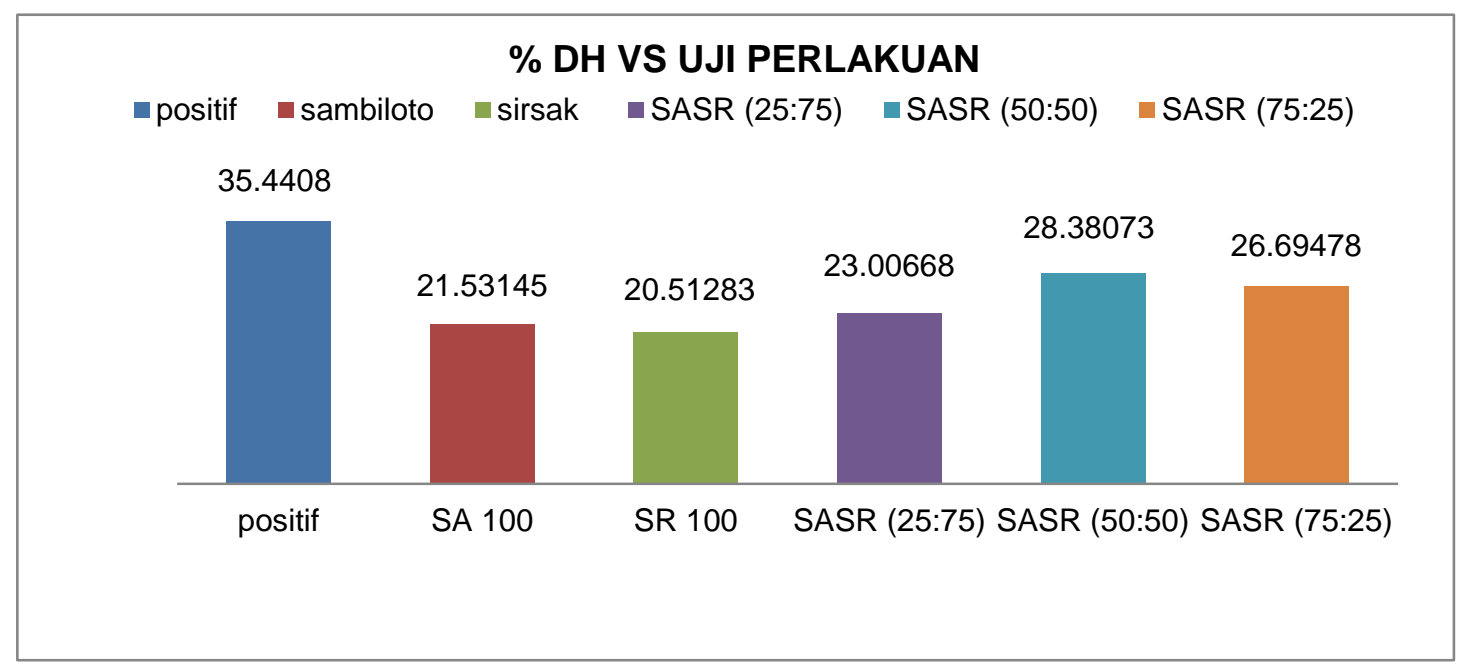

Gambar 2. Histogram rata-rata penurunan kadar gula darah masing-masing kelompok perlakuan

\section{Berdasarkan gambar 2 masing-} masing kelompok perlakuan mengalami penurunan kadar gula darah. Kelompok perlakuan kontrol positif memiliki perbedaan yang signifikan dengan kelompok SA 100, SR 100, SASR 25:75, dan SASR 75:25, hal ini menunjukkan daya penurunan kadar glukosa darah kelompok SA 100, SR 100, SASR 25:75, dan SASR 75:25 kurang dari daya penurunan kadar glukosa darah kelompok positif glibenklamid yaitu sebesar $35,4408 \%$ meskipun kelompok SA 100 menunjukkan adanya penurunan kadar gula darah sebesar 21,53145\%, kelompok SR 100 sebesar 20,51283\%, kelompok SASR 25:75 sebesar $23,00668 \%$, dan kelompok SASR 75:25 sebesar 26,69478\%. Kelompok positif jika dibandingkan dengan kelompok SASR 50:50 memiliki perbedaan yang signifikan, hal ini menunjukkan daya penurunan kadar glukosa darah kelompok SASR 50:50 sama dengan daya penurunan kadar glukosa darah kontrol positif glibenklamid. Daya penurunan kadar gula darah kelompok SASR 50:50 sebesar $28,38073 \%$ dan daya penurunan kadar gula darah kelompok positif glibenklamid sebesar $35,4408 \%$. Namun kelompok kontrol positif glibenklamid lebih efektif dalam menurnkan kadar glukosa darah dibandingkan dengan kelompok yang lainnya. Pemberian kombinasi ekstrak herba sambiloto dan daun sirsak lebih efektif dalam menurunkan kadar gula darah dibandingkan bentuk tunggal dengan persentase daya hipoglikemi tertinggi yaitu kelompok SASR 50:50.

Ekstrak herba sambiloto mengandung senyawa aktif yaitu andrografolid yang dapat menurunkan kadar glukosa darah melalui peningkatan protein pembawa glukosa dalam jaringan (GLUT 4) dan melalui penghambatan a-glukosidase dalam saluran pencernaan. ${ }^{9}$ Daun sirsak memiliki senyawa flavonoid (quersetin) sebagai agen hipoglikemik dengan menstimulasi sekresi insulin, memperbaiki kerusakan pada sel $\beta$ pankreas, dan inhibitor enzim $\alpha$-glukosidase. ${ }^{5}$

\section{KESIMPULAN}

Kombinasi ekstrak herba sambiloto (Andrographis paniculata (Burm. F.) Nees.) dan daun sirsak (Annona muricata L.) dapat menurunkan kadar gula darah dengan dosis $10,5 \mathrm{mg} / \mathrm{kgBB}$ ekstrak herba sambiloto dan 50 $\mathrm{mg} / \mathrm{kgBB}$ ekstrak daun sirsak dan pemberian kombinasi ekstrak herba sambiloto 
Uji efek antidiabetes kombinasi ekstrak herba sambiloto (Andrographis paniculata (Burm. F.) Nees.) dan daun sirsak (Annona muricata L.) pada tikus jantan yang diinduksi aloksan

(Andrographis paniculata (Burm. F.) Nees.) dan daun sirsak (Annona muricata L.) lebih efektif menurunkan kadar gula darah dibandingkan bentuk tunggalnya

\section{DAFTAR PUSTAKA}

1. Perkeni PEI. Konsensus Pengendalian dan Pencegahan Diabetes Melitus Tipe 2 di Indonesia (The Consensus of Control and Prevention of Type 2 Diabetes Mellitus). Jakarta: Perkeni Indones Soc Endocrinol. 2011.

2. Iskandar M. Health Triad (Body, Mind, And System). Jakarta: PT Elex Media Komputindo, Kelompok Gramedia; 2010.

3. Baroroh F, Aznam N, Susanti H. Uji efek antihiperglikemik ekstrak etanol daun kacapiring (Gardenia augusta Merr.) pada tikus putih jantan galur wistar. Pharm Ed Mei 2011. 2011;1(1):43-53.

4. Adjie S. Dahsyatnya Sirsak Tumpas Penyakit. Jakarta: Pustaka Bunda. 2011.

5. Ratya A. Antidiabetic Potential Of Soursop Leaf Extract (Annona muricata L.) as a treatment for type 2 diabetes mellitus. J Agromedicine. 2014;1(1):61-66.

6. Risyani R, Jamaluddin AW, Mursalim MF. Aktivitas ekstrak daun sirsak (Annona muricata L.) secara in vivo terhadap scabies pada kambing kacang (Capra hircus). As-Syifaa J Farm. 2018;10(2):179-189.
7. Firmansyah D, Bachri M, Nurkhasanah N. Pengaruh pemberian ekstrak etanol dan kloroform daun sirsak terhadap kolesterol total dan trigliserida pada tikus yang diinduksi aloksan. Pharmaciana. 2016;6(1):47-54.

8. Harianja S. Isolasi Senyawa Alkaloida Dari Daun Tumbuhan Sambiloto (Andrographis Paniculata (Burm. F.) Ness). 2011.

9. Burhanuddin MA, Manggau FA. Pengaruh Pemberian kombinasi ekstrak daun kelor (Morinaga oleifera) dan herba sambiloto (Andrographis paniculata) terhadap penurunan kadar glukosa darah mencit jantan (Mus musculus) akibat efek deksametason. JST Kesehat. 2014;4(1):17-24.

10. Rosnaeni R, Ratnawati H, Kastilani S. Effect of ethanol extract sambiloto leaf (Andrographidis folium) against blood glucose level in male swiss webster mice induced by aloxan compared to jamu $\mathrm{d}$. None. 2013;1(1).

11. Suherman SK. Insulin dan antidiabetik oral. Dalam: Gunawan, Setiabudy, Nafrialdi, Elysabeth. Farmakol Dan Ter. 2009;481-495.

12. Maliangkay HP, Rumondor R, Walean M. Uji efektifitas antidiabetes ekstrak etanol kulit buah manggis (Garcinia mangostana L) pada tikus putih (Rattus norvegicus) yang diinduksi aloksan. Chem Prog. 2018;11(1). 